Research Article

\title{
Prevalence, Awareness, Treatment, and Control of Hypertension among Young and Middle-Aged Adults: Results from a Community-Based Survey in Rural Tanzania
}

\author{
Alfa J. Muhihi $\mathbb{D},{ }^{1,2,3}$ Amani Anaeli, ${ }^{4}$ Rose N. M. Mpembeni, ${ }^{5}$ Bruno F. Sunguya, ${ }^{1}$ \\ Germana Leyna, ${ }^{5}$ Deodatus Kakoko, ${ }^{6}$ Anna Tengia Kessy, ${ }^{1}$ Mary Mwanyika Sando, ${ }^{2}$ \\ Marina Njelekela, ${ }^{7,8}$ and David P. Urassa ${ }^{1}$ \\ ${ }^{1}$ Department of Community Health, Muhimbili University of Health and Allied Sciences, United Nations Road, Upanga, \\ Dar es Salaam, Tanzania \\ ${ }^{2}$ Africa Academy for Public Health, Plot \# 802, Mwai Kibaki Road, Mikocheni, Dar es Salaam, Tanzania \\ ${ }^{3}$ The Lown Scholars Program, Department of Global Health and Population, Harvard T.H. Chan School of Public Health, Boston, \\ MA, USA \\ ${ }^{4}$ Department of Development Studies, Muhimbili University of Health and Allied Sciences, United Nations Road, Upanga, \\ Dar es Salaam, Tanzania \\ ${ }^{5}$ Department of Epidemiology and Biostatistics, Muhimbili University of Health and Allied Sciences, United Nations Road, \\ Upanga, Dar es Salaam, Tanzania \\ ${ }^{6}$ Department of Behavioral Sciences, Muhimbili University of Health and Allied Sciences, United Nations Road, Upanga, \\ Dar es Salaam, Tanzania \\ ${ }^{7}$ Department of Physiology, Muhimbili University of Health and Allied Sciences, United Nations Road, Upanga, Dar es Salaam, \\ Tanzania \\ ${ }^{8}$ Deloitte Consulting Limited, Aris House, Plot \# 152, Haile Selassie Road, Oysterbay, Dar es Salaam, Tanzania
}

Correspondence should be addressed to Alfa J. Muhihi; selukundo@gmail.com

Received 19 May 2020; Accepted 25 August 2020; Published 3 September 2020

Academic Editor: Fulvio Morello

Copyright ( 92020 Alfa J. Muhihi et al. This is an open access article distributed under the Creative Commons Attribution License, which permits unrestricted use, distribution, and reproduction in any medium, provided the original work is properly cited.

Background. Hypertension, which is the single most important risk factor for CVDs, is increasing at an alarming rate in most developing countries. This study estimated the prevalence, awareness, treatment, and control of hypertension among young and middle-aged adults in rural Morogoro, Tanzania. Furthermore, it explored factors associated with both prevalence and awareness of hypertension. Methods. A cross-sectional survey was conducted as part of the cluster randomized controlled study of community health workers (CHWs) interventions for reduction of blood pressure in a randomly selected sample of young and middle-aged population in rural Morogoro. Sociodemographics, lifestyle-related factors, history of diagnosis, and treatment for hypertension were collected using a questionnaire adopted from the STEPS survey tool. Blood pressure, height, and weight were measured at home following standard procedures. Descriptive statistics were used to estimate prevalence, awareness, treatment, and control of hypertension. Multiple logistic regression models were used to assess determinants of hypertension and awareness. Result. The prevalence of hypertension was 29.3\% (95\% CI: 27.7-31.0). Among individuals with hypertension, only $34.3 \%$ were aware of their hypertension status. Only around one-third (35.4\%) of those who were aware of their hypertension status were currently on antihypertensive medication. Hypertension control was attained in only $29.9 \%$ among those on medications. Older age $(p<0.001)$, use of raw table salt $(p<0.001)$, and being overweight/obese $(p<0.001)$ were associated with hypertension. Predictors of awareness of hypertension status were older age, being a female, higher socioeconomic status, use of raw table salt, a history of diabetes, and overweight/obesity (all $p<0.001$ ). Alcohol drinking was associated with low awareness for hypertension status $(p<0.001)$. Conclusion. There is high prevalence of hypertension with low rates of awareness, treatment, and control among young and middle-aged adults in rural Tanzania. Community-level health promotion and screening campaigns for hypertension and other CVD risk factors should be intensified. 


\section{Introduction}

Cardiovascular diseases (CVDs) are the leading cause of mortality globally [1]. Hypertension, which is defined as systolic blood pressure (SBP) $\geq 140 \mathrm{mmHg}$ and/or diastolic blood pressure $(\mathrm{DBP}) \geq 90 \mathrm{mmHg}$ or regular use of antihypertensive medications [2], is the single most important risk factor for CVDs [3, 4], accounting for $45 \%$ of deaths caused by ischemic heart diseases and $51 \%$ of deaths caused by cerebrovascular disease [5]. In 2010, the number of people with hypertension was estimated to be 1.4 billion, and with current trend, it is projected to exceed 1.6 billion by 2025 [6].

In 2013, the WHO set a global target for the control of noncommunicable diseases (NCDs), which included a $25 \%$ relative reduction in the prevalence of high blood pressure by 2025 [7]. While the prevalence of hypertension declined by $2.6 \%$ between 2000 and 2010 in high-income countries (HICs), it increased by $7.7 \%$ in low- and middle-income countries (LMICs) during the same period [6]. Similarly, awareness and control for hypertension increased substantially in HICs compared to LMICs [6]. Sub-Saharan Africa (SSA) has the highest rates of hypertension in the world. A study conducted in Soweto, South Africa, reported a prevalence of up to $54.1 \%$ [8]. Finding from a systematic review and meta-analysis of studies conducted in SSA reported a pooled prevalence of hypertension of $30 \%$, awareness of $27 \%$ among hypertensive individuals, and treatment rates of $18 \%$ with only $7 \%$ being controlled [9]. In Kenya, findings from a national survey indicated a prevalence of hypertension of $24.5 \%$, awareness of $15.6 \%$ among individual with hypertension, $26.9 \%$ of those aware were on treatment, and $51.5 \%$ were controlled [10].

In Tanzania, available data indicate that CVD risk factors were very low in 1990s [11] but have continued to rise especially among young and middle-aged adults [12, 13]. Data from a national representative STEPS survey indicated the prevalence of hypertension to be $25.9 \%$ [14]. A study in Mafia Island in Tanzania reported a high prevalence of $49.5 \%$ [15]. Despite the increasing prevalence of hypertension and other CVD risk factors in Tanzania, studies examining awareness, treatment, and control of hypertension are scarce. Both, awareness and treatment for hypertension have been reported to be low in Tanzania. A study in northwestern parts of the country reported awareness and treatment rates of $9.4 \%$ and $7.1 \%$, respectively [16]. In contrast, a study in Mafia Island reported higher rates of both awareness (71.2\%) and treatment (79.4\%) for hypertension [15]. Building on the little existing data, this study assessed the prevalence, awareness, treatment, and control of hypertension and explored their predictors in a random sample of young and middle-aged adults in rural Morogoro.

\section{Materials and Methods}

2.1. Study Design and Setting. Data analyzed for this study were collected as a baseline survey for cluster randomized controlled trial of community health workers (CHWs) interventions for reduction of blood pressure. The study was conducted in Kilombero and Ulanga districts in Morogoro region, approximately 450 kilometers southwest of Tanzania's commercial capital of Dar es Salaam. The two districts were selected purposely because of high CVD deaths previously reported in the study area [17].

\subsection{Study Participants and Eligibility Criteria.} Participants were adults aged 25-64 years, residents of the study districts who provided a written informed consent. A resident was defined as an individual who had stayed in the study area for at least 4 months continuously regardless of whether she/he had slept in that household a night before the interview [18]. Household was defined as group of people who served food from the same pot. Self-reported pregnant women and bed-ridden and/or mentally ill health individuals were excluded.

2.3. Sample Size Estimation and Sampling Procedures. The sample size for the baseline cross-sectional survey was estimated according to the WHO stepwise approach to chronic disease risk factors surveillance (STEPS) [19]. The sample size was calculated for $95 \%$ CI $(z=1.96)$ on the basis of a $5 \%$ margin of error, an estimated prior national prevalence of hypertension of $25.9 \%$ [14], a design effect of 1.25 , and an anticipated nonresponse rate of $10 \%$. Participants were adults aged 25-64 years and categorized into four age-sex groups, resulting into 8 strata. The resulting minimum sample size 3,145 .

We used a multistage cluster sampling technique where villages were considered as clusters. A random sample of 12 villages was drawn from a list of 38 villages with active CHWs stratified by district. For each study, village random sample of households was drawn, and at each household, one eligible respondent was selected by a simple random procedure using the next birthday rule. If the selected individual for interview was not available after two home visit attempts, the next eligible member was interviewed.

2.4. Data Collection. Data collection was conducted by a team of trained research assistants with experience in conducting health and demographic surveys. A modified WHO STEPS questionnaire for noncommunicable diseases surveillance was used to gather sociodemographic and economic information and behavioral CVD risk factors. Sociodemographic information including age, gender, marital status, education level, and occupation were collected. Age was collected as a continuous variable, while education was measured as the highest level of formal education attained. Marital status was grouped into never married, married or living together, divorced or separated, and widow. Occupation was assessed as a categorical variable as none or housewife, formal employment (public/ private), peasant/pastoralist, petty business, and others.

We collected data on household ownership of items such as radio, television, telephone, sofa, refrigerator, bicycle, and 
car; having working electricity, house ownership, and house construction materials (floor, wall, and roof); source of fuel for cooking and lighting; source of water for drinking and for home use; sanitation facility; and ownership of livestock. A household wealth index in quintiles was then generated following descriptions in the Demographic Health Survey (DHS) toolkit [20] and was used as a proxy for household socioeconomic status.

Behavioral CVD risk factors assessed included smoking, alcohol drinking, and dietary habits. For smoking, questions probed current and past smoking, while for alcohol, they probed current and past alcohol drinking. Dietary assessment included intakes of fruits, vegetables, and use of raw table salt.

2.5. Measurements. Blood pressure was measured using a digital blood pressure machine (OMRON HEM-712C, Omron Healthcare, Inc.). Trained research assistants measured blood pressure on the left arm with participant in a seated position. The first reading was taken after at least 5 minutes of resting. The second and third readings were taken halfway and at the end of interview, respectively. An average of three readings was used during analysis. Participants who had elevated blood pressure had a repeat measurement performed on the following day to confirm their elevated blood pressure. Anthropometric measurements included weight and height. Body weight was measured to the nearest $0.1 \mathrm{~kg}$ using a SECA 803 digital scale placed on flat ground with participant wearing light clothing and with no shoes. Height was measured to the nearest $0.1 \mathrm{~cm}$ with participant in a standing position with heels perpendicular to the portable stadiometer.

2.6. Definition of Key Terms. Hypertension was defined as average systolic blood pressure (SBP) $\geq 140 \mathrm{mmHg}$ and/or diastolic blood pressure (DBP) $\geq 90 \mathrm{mmHg}$ or currently taking blood pressure lowering medications in accordance with the Seventh Report of the Joint National Committee on Prevention, Detection, Evaluation and Treatment of High Blood Pressure [2]. Awareness of hypertension was defined as self-report of diagnosis of hypertension among participants who had their blood pressure checked before and responded "YES" to the question "Have you ever been told by the doctor or other health worker that you have hypertension?" Treatment for hypertension was defined as taking blood pressure lowering medications at the time of the survey among those aware of their hypertension status. Control of hypertension was considered for individuals on blood pressure lowering medications if they had systolic blood pressure $(\mathrm{SBP})<140 \mathrm{mmHg}$ and diastolic blood pressure $(\mathrm{DBP})<90 \mathrm{mmHg}$.

2.7. Data Analysis. Data were entered and analysed using IBM-Statistical Package for Social Sciences (SPSS Inc., Chicago, IL, USA) version 20 software for Windows. Data were presented in a frequency distribution with relative frequencies (\%) for categorical variables and a measure of central tendency (mean) and of variability (SD) for symmetrically distributed continuous variables. For asymmetrically distributed continuous variables, median with interquartile range (IQR) was used to describe the data. Comparisons between groups were performed using the chi-squared test and independent samples $t$-test (or ANOVA) for categorical and continuous variables, respectively.

Binary logistic regression was performed to examine the relationship of each independent variable with hypertension and awareness of hypertension status. Predictor variables were age, sex, wealth status, marital status, education level, place of residence, occupation, smoking status, alcohol drinking status, use of raw table salt, fruits and vegetable consumption, and body mass index. Variables with $p<0.2$ in bivariate logistic regression analysis were retained in the multiple logistic regression analysis. Selection of the best predicting model was performed conducting forward, backward, and stepwise model selection procedures. Overall fitness of the model was assessed using the Pearson chi-squared test and Hosmer-Lemeshow goodness-of-fit test. We first assessed the correlation and strength of correlation between variables in the regression model, using variance inflation factor (VIF) with a cutoff value of $\leq 5$ to avoid problem with multicollinearity. Adjusted odds ratio (AOR) and their corresponding 95\% confidence intervals (95\% CI) are presented as measures of association. Statistical significance was considered based on a twosided $p$ value $\leq 0.05$.

\section{Results}

3.1. Characteristics of Study Participants. Among 3145 individuals who were approached for participation, 3000 (95.4\%) had complete data. Characteristics of the study participants are summarized in Table 1. The median (interquartile range (IQR)) age of the participants was 39 [21-38] years and was significantly higher among men. Higher proportion of the participants $(35.7 \%)$ was of younger age (25-34 years), while $13.7 \%$ was of older age (55-64 years). Majority of the participants were women (74.1\%), were married (71.5\%), and had primary education (80.4\%). Peasant/pastoralist was the predominant occupation $(92.5 \%)$. Significant sex differences were also observed for marital status, education level, and occupation.

Only 5.9\% of the participants was current smokers, and $19.7 \%$ was current alcohol drinkers. Both smoking and alcohol drinking were significantly higher in men (all $p<0.001)$. Majority of the participants $(85.2 \%)$ reported to have ever used raw table salt, with $6.8 \%$ reporting to do so always. Men reported to use raw table salt more frequently than women $(p=0.026)$. The proportion of participants who consumed vegetables and fruits 5-7 days/week was $63.9 \%$ and $7.9 \%$, respectively. Women consumed vegetables more frequent than men $(p<0.001)$. The proportion of participants who were overweight and obese was $28.5 \%$ and $16.3 \%$, respectively, and both were significantly higher in women $(p<0.001)$. 
TABLE 1: Characteristics of the study participants.

\begin{tabular}{|c|c|c|c|c|}
\hline Variable & $\begin{array}{c}\text { All participants } \\
N=3,000 \\
n(\%)\end{array}$ & $\begin{array}{c}\text { Males } \\
N=778 \\
n(\%)\end{array}$ & $\begin{array}{c}\text { Females } \\
N=2,222 \\
n(\%)\end{array}$ & $p$ value \\
\hline Age (years) (median (IQR)) & $39(31.0-48.0)$ & $41(32.0-51.0)$ & $38(30.8-47.0)$ & $<0.001$ \\
\hline $\begin{array}{l}\text { Age (years) } \\
25-34 \\
35-44 \\
45-54 \\
55-64 \\
\end{array}$ & $\begin{array}{l}1072(35.7) \\
888(29.6) \\
628(20.9) \\
412(13.7)\end{array}$ & $\begin{array}{l}238(30.6) \\
208(26.7) \\
182(23.4) \\
150(19.3)\end{array}$ & $\begin{array}{l}834(37.5) \\
680(30.6) \\
446(20.1) \\
262(11.8)\end{array}$ & $<0.001$ \\
\hline $\begin{array}{l}\text { Wealth status } \\
\text { Poorest } \\
\text { Poor } \\
\text { Middle } \\
\text { Rich } \\
\text { Richest } \\
\end{array}$ & $\begin{array}{l}694(23.1) \\
497(16.6) \\
579(19.3) \\
630(21.0) \\
600(20.0)\end{array}$ & $\begin{array}{l}190(24.4) \\
137(17.6) \\
150(19.3) \\
134(17.2) \\
167(21.5) \\
\end{array}$ & $\begin{array}{l}504(22.7) \\
360(16.2) \\
429(19.3) \\
496(22.3) \\
433(19.5)\end{array}$ & 0.046 \\
\hline $\begin{array}{l}\text { District } \\
\text { Kilombero } \\
\text { Ulanga }\end{array}$ & $\begin{array}{l}1500(50.0) \\
1500(50.0)\end{array}$ & $\begin{array}{l}344(44.2) \\
434(55.8)\end{array}$ & $\begin{array}{l}1156(52.0) \\
1066(48.0)\end{array}$ & $<0.001$ \\
\hline $\begin{array}{l}\text { Marital status } \\
\text { Never married } \\
\text { Married } \\
\text { Separated/divorced/widowed }\end{array}$ & $\begin{array}{c}383(12.8) \\
2144(71.5) \\
473(15.8)\end{array}$ & $\begin{array}{c}97(12.5) \\
613(78.8) \\
68(8.7) \\
\end{array}$ & $\begin{array}{c}286(12.9) \\
1531(68.9) \\
405(18.2)\end{array}$ & $<0.001$ \\
\hline $\begin{array}{l}\text { Education level } \\
\text { No formal education } \\
\text { Primary education } \\
\text { Secondary education } \\
\text { College/university education }\end{array}$ & $\begin{aligned} & 297(9.9) \\
& 2411(80.4) \\
& 255(8.5) \\
& 37(1.2) \\
&\end{aligned}$ & $\begin{aligned} & 32(4.1) \\
& 628(80.7) \\
& 99(12.7) \\
& 19(2.4) \\
&\end{aligned}$ & $\begin{array}{c}265(11.9) \\
1783(80.2) \\
156(7.0) \\
18(0.8) \\
\end{array}$ & $<0.001$ \\
\hline $\begin{array}{l}\text { Occupation } \\
\text { Farmer } \\
\text { House wife } \\
\text { Employed } \\
\text { Business } \\
\text { Others } \\
\end{array}$ & $\begin{aligned} & 2775(92.5) \\
& 79(2.6) \\
& 27(0.9) \\
& 80(2.7) \\
& 39(1.3) \\
&\end{aligned}$ & $\begin{array}{c}730(93.8) \\
0(0.0) \\
14(1.8) \\
25(3.2) \\
9(1.2)\end{array}$ & $\begin{array}{c}2052(92.3) \\
72(3.2) \\
13(0.6) \\
55(2.5) \\
30(1.4)\end{array}$ & $<0.001$ \\
\hline $\begin{array}{l}\text { Current smoking status } \\
\text { No } \\
\text { Yes }\end{array}$ & $\begin{array}{c}2824(94.1) \\
176(5.9)\end{array}$ & $\begin{array}{l}634(81.5) \\
144(18.5)\end{array}$ & $\begin{array}{c}2190(98.6) \\
32(1.4)\end{array}$ & $<0.001$ \\
\hline $\begin{array}{l}\text { Current alcohol drinking status } \\
\text { No } \\
\text { Yes } \\
\end{array}$ & $\begin{array}{c}2409(80.3) \\
591(19.7) \\
\end{array}$ & $\begin{array}{l}547(70.3) \\
231(29.7) \\
\end{array}$ & $\begin{array}{c}1862(80.3) \\
360(19.7)\end{array}$ & $<0.001$ \\
\hline $\begin{array}{l}\text { Use of raw table salt } \\
\text { Never } \\
\text { Sometimes } \\
\text { Always }\end{array}$ & $\begin{array}{c}446(14.9) \\
2351(78.4) \\
203(6.8) \\
\end{array}$ & $\begin{aligned} & 95(12.2) \\
& 636(81.7) \\
& 47(6.0) \\
&\end{aligned}$ & $\begin{array}{c}351(15.8) \\
1715(77.2) \\
156(7.0) \\
\end{array}$ & 0.026 \\
\hline $\begin{array}{l}\text { Fruits consumption/week } \\
5-7 \text { days } \\
1-4 \text { days } \\
\text { Never }\end{array}$ & $\begin{array}{c}238(7.9) \\
2168(72.3) \\
594(19.8) \\
\end{array}$ & $\begin{aligned} & 63(8.1) \\
& 567(72.9) \\
& 148(19.0) \\
&\end{aligned}$ & $\begin{array}{c}175(7.9) \\
1601(72.1) \\
446(20.1) \\
\end{array}$ & 0.814 \\
\hline $\begin{array}{l}\text { Consumption of vegetables/week } \\
5-7 \text { days } \\
1-4 \text { days } \\
\text { Never }\end{array}$ & $\begin{array}{c}1916(63.9) \\
1043(34.8) \\
41(1.4) \\
\end{array}$ & $\begin{aligned} & 433(55.7) \\
& 333(42.8) \\
& 12(1.5) \\
&\end{aligned}$ & $\begin{array}{c}1483(66.7) \\
710(32.0) \\
29(1.3)\end{array}$ & $<0.001$ \\
\hline $\begin{array}{l}\text { History of diabetes mellitus } \\
\text { No } \\
\text { Yes }\end{array}$ & $\begin{array}{c}2971(99.0) \\
29(1.0)\end{array}$ & $\begin{array}{c}770(99.0) \\
8(1.0)\end{array}$ & $\begin{array}{c}2201(99.1) \\
21(0.9)\end{array}$ & 0.838 \\
\hline $\begin{array}{l}\text { Body mass index }\left(\mathrm{BMI}\left(\mathrm{kg} / \mathrm{m}^{2}\right)\right) \\
\text { Underweight } \\
\text { Normal } \\
\text { Overweight } \\
\text { Obese }\end{array}$ & $\begin{array}{c}93(3.1) \\
1563(52.1) \\
855(28.5) \\
489(16.3)\end{array}$ & $\begin{aligned} 30 & (3.9) \\
531 & (68.3) \\
170 & (21.9) \\
47 & (6.0)\end{aligned}$ & $\begin{array}{c}63(2.8) \\
1032(46.4) \\
685(30.8) \\
442(19.9)\end{array}$ & $<0.001$ \\
\hline
\end{tabular}


TABle 1: Continued.

\begin{tabular}{lccc}
\hline Variable & $\begin{array}{c}\text { All participants } \\
N=3,000 \\
n(\%)\end{array}$ & $\begin{array}{c}\text { Males } \\
N=778 \\
n(\%)\end{array}$ & $\begin{array}{c}\text { Females } \\
N=2,222 \\
n(\%)\end{array}$ \\
\hline $\begin{array}{l}\text { Blood pressure (mmHg) } \\
\text { Mean SBP (SD) }\end{array}$ & $127.2(20.8)$ & $131.1(17.9)$ & $125.9(20.8)$ \\
Mean DBP (SD) & $83.5(12.6)$ & $83.9(11.9)$ & $83.3(12.8)$ \\
\hline Blood pressure profile & & & \\
Normal BP & $954(31.8)$ & $374(48.1)$ & $891(35.6)$ \\
Prehypertension & $1198(39.9)$ & $157(20.2)$ & $343(15.4)$ \\
High BP (stage 1) & $500(16.7)$ & $84(10.8)$ & $264(11.9)$ \\
High BP (stage 2) & $348(11.6)$ & & $<0.298$ \\
\hline
\end{tabular}

3.2. Blood Pressure Profile. Distribution of blood pressures of study participants is summarized in Table 1 . The mean systolic blood pressure (SBP) was $127.2 \pm 20.8 \mathrm{mmHg}$ and that of diastolic blood pressure (DBP) was $83.5 \pm 12.6 \mathrm{mmHg}$. Mean SBP was significantly higher among men compared to women $(p<0.001)$. However, no differences were observed for mean DBP. Both SBP and DBP were higher among older compared to young participants. There was a linear increase in SBP and DBP with age in both men and women, although DBP seemed to plateau at 45 years of age (Figure 1). About one-third (31.8\%) had normal blood pressure, $39.9 \%$ had blood pressure in the prehypertension range, $16.7 \%$ had stage 1 hypertension, and $11.6 \%$ had stage 2 hypertension (Figure 2). The proportion of participants with prehypertension and stage 1 hypertension was higher in men compared to women $(p<0.001)$.

3.3. Prevalence, Awareness, Treatment, and Control for Hypertension. The prevalence of hypertension was $29.3 \%$ (Table 2) and increased sharply with age from $12.5 \%$ among $25-34$ years old age group to $53.2 \%$ among $55-64$ years groups, respectively $(p<0.001)$. Hypertension was higher among separated/divorced/widowed $(p<0.001)$, among smokers $(p=0.052)$, among current alcohol drinkers $(p=0.022)$, and among overweight and obese participants $(p<0.001)$. Participants who always used raw table salt had significantly higher rates of hypertension compared to those who never used $(p<0.001)$.

Among 880 participants with hypertension, 302 (34.3\%) were aware of their hypertension status, while the remaining $578(65.7 \%)$ were newly diagnosed. Of the 302 participants aware of their hypertension status, only 107 (35.4\%) were on blood pressure lowering medication, of whom 32 (29.9\%) had controlled blood pressure (Figure 3).

Awareness of hypertension was significantly higher among older compared to young participants $(p=0.016)$, women compared to men $(p<0.001)$, those with high socioeconomic status $(p<0.01)$, and those with a history of diabetes mellitus $(p<0.01)$. Awareness was low among alcohol drinkers and participants with normal BMI (both $p<0.01)$. Treatment for hypertension was again higher among older compared to younger participants $(p<0.001)$, individuals who used raw table salt, those who consumed fruits more frequently (all $p<0.01$ ), and those with a history of diabetes mellitus $(p<0.05)$. Blood pressure control was higher for women, individuals with low socioeconomic status, and those who never used raw table salt. However, none of the factors associated with hypertension control attained a statistical significance level.

3.4. Predictors of Prevalence and Awareness of Hypertension. Significant predictors of hypertension in multivariate analysis were older age, use of raw table salt, and higher BMI (Table 3). Compared to young, older participants were 8 times more likely to be hypertensive ( $\mathrm{AOR}=8.45,95 \% \mathrm{CI}$ : $6.33-11.30, p<0.001)$. Participants who reported using raw table salt had more than twice the odds of being hypertensive $(\mathrm{AOR}=2.27,95 \% \mathrm{CI}: 1.73-2.99, p<0.001)$. Overweight participants had $53 \%$ increased risk $(\mathrm{AOR}=1.53,95 \% \mathrm{CI}$ : $1.26-1.88, p<0.001$ ), while obese participants had more than double the risk for hypertension $(\mathrm{AOR}=2.58,95 \%$ 2.04-3.28, $p<0.001$ ).

As for awareness of hypertension (Table 4), predicting factors included older age and being female. Older participants were more than 2 times likely to be aware of their hypertension compared to younger participants $(\mathrm{AOR}=2.05$, 95\% CI: $1.24-3.39, p<0.001)$. Similarly, women had more than twice the odds of being aware of hypertension compared to men $(\mathrm{AOR}=2.47,95 \% \mathrm{CI}: 1.67-3.66, p<0.001)$. Other significant predictors of awareness of hypertension were higher socioeconomic status, alcohol drinking, use of raw table salt, history of diabetes mellitus, and higher BMI. Overweight and obese participants were more than 2 times more likely to be aware of their hypertension compared to normal weight participants. Alcohol drinking was associated with $51 \%$ decreased odds of being aware of hypertension status $(\mathrm{AOR}=0.49,95 \% \mathrm{CI}: 0.32-0.74, p=0.001)$.

\section{Discussion}

This study provides information on prevalence, awareness, treatment, and control of hypertension and their correlates among young and middle-aged adults in rural Tanzania. Key findings were high prevalence of hypertension, low levels of awareness and treatment rates, and poor control among those on treatment. High prevalence of hypertension was driven by older age, use of raw table salt, and higher BMI. Significant predictors of awareness of hypertension were older age, being female, wealth status, drinking alcohol, use of raw table salt, a history of diabetes mellitus, and higher BMI. 


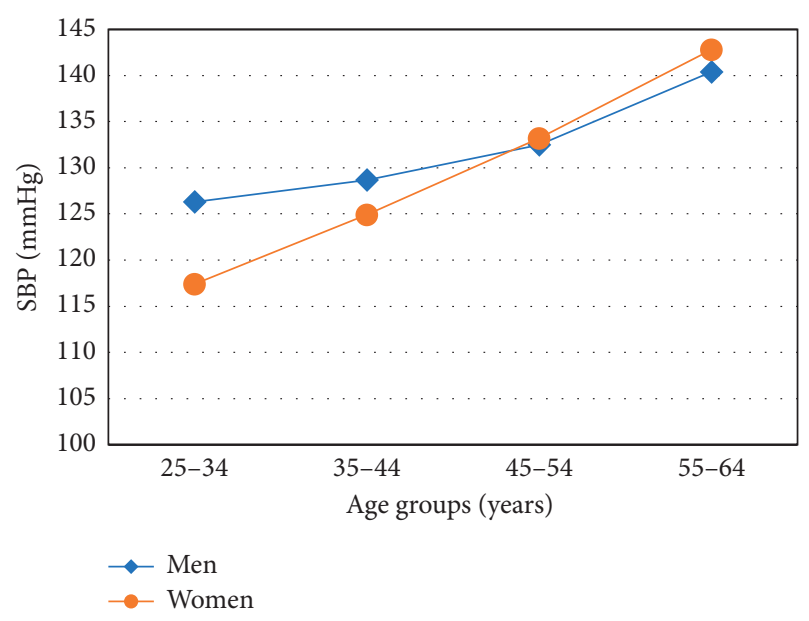

(a)

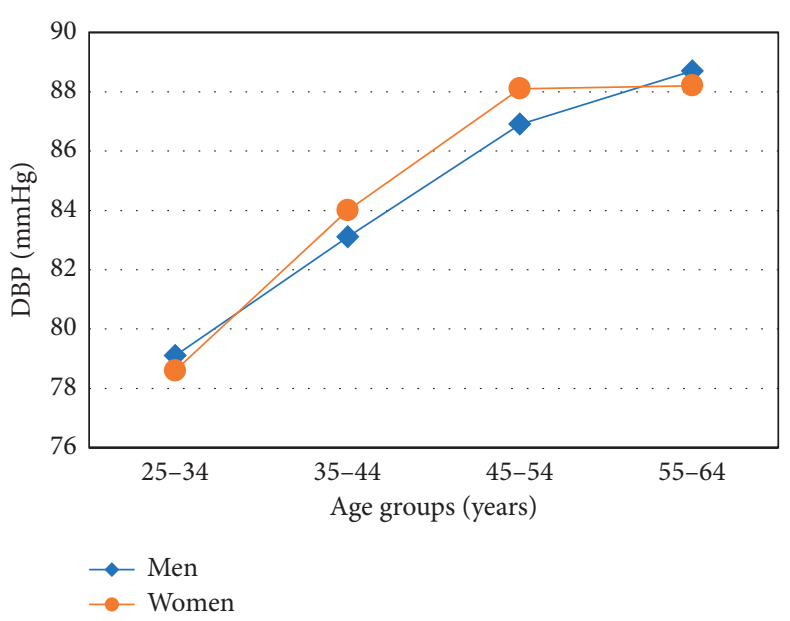

(b)

FIgURE 1: Trend of systolic and diastolic blood pressure by age and sex.

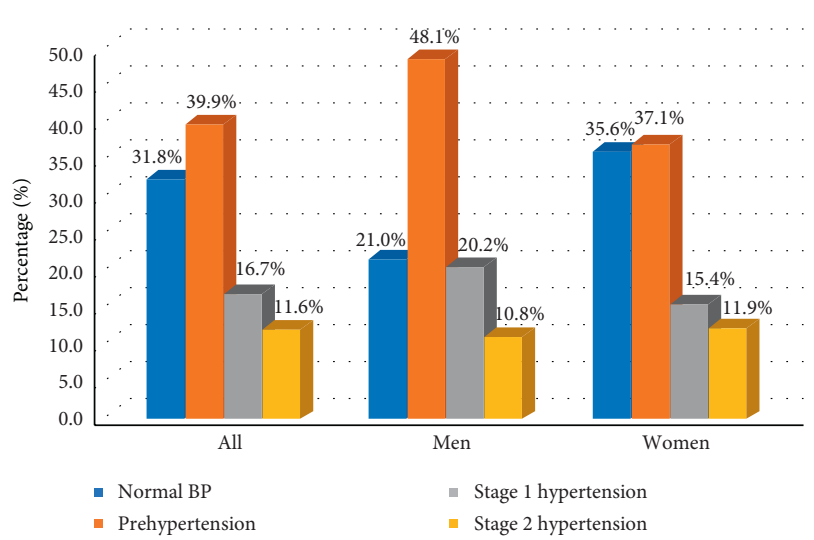

Figure 2: Distribution of blood pressure by sex.

4.1. Prevalence and Determinants of Hypertension. The prevalence of hypertension of $29.3 \%$ found in our study was comparable to previous report from a community-based survey in Northern Tanzania [39], which found a prevalence of $28.0 \%$. However, it was higher compared to another community-based study in rural Mwanza [16], which reported a prevalence of $8 \%$ and that of $25.9 \%$ reported in the national representative STEPS survey conducted in 2012 [14]. Low prevalence of hypertension reported in rural Mwanza may be attributable to inclusion of younger participants as more than one-third (38.9\%) were aged 15-24 years. Although reports from rural Mafia and Hai districts in Tanzania $[15,40]$ found higher prevalence of hypertension than observed in our study, the study in Hai district comprised of participants aged 70 years and above in whom hypertension is not uncommon. Overall, two-fifths (39.9\%) of participants had prehypertension. While primary prevention strategies should target the general population, more importantly should focus at prehypertensive individuals who are at increased risk of developing hypertension.

In our study, hypertension increased with age ranging from $12.5 \%$ among $25-34$ years old to $53.2 \%$ among those aged 55-64 years. After controlling for other factors, participants aged 55-64 years were eight times more likely to be hypertensive compared to their counterparts aged 25-34 years. Other studies have reported a similar trend $[10,41,42]$. Changes in arteriolar stiffness and elasticity and decreased ability to respond to abrupt hemodynamic changes $[43,44]$ that occur with advancing age have been implicated for the rise in blood pressure in elderly. Furthermore, hypertension was higher among separated/divorced, and/or widowed, which is consistent with reports from other studies [45, 46]. Marriage has been shown to be protective against CVDs [47]. Marital disruption on the other hand is associated with increased risk for CVDs and mortality in middle-aged women [21, 22], probably due to psychosocial stress [23]. We found lowest prevalence of hypertension among never married, which may be attributable to their young age.

In our study, $44.8 \%$ of the participants was either overweight or obese. There is need to increase awareness on the importance of optimal body weight, physical activity, and healthy dietary habits given that the main staple food in the area is white rice. Consistent with findings from other studies $[10,24,25]$, we found positive association between overweight and obesity with hypertension. Similarly, a study conducted among Kenyan women was also reported. These findings suggest the need for healthcare providers to prioritize screening for hypertension to overweight and obese clients that come in contact with the healthcare system. Our findings of association between alcohol drinking and smoking with hypertension were also consistent with report from other studies $[10,26]$.

Use of raw table salt was associated with more than twice increased odds of being hypertensive. High-salt diet leads to the increase in plasma volume and consequently an increase in blood pressure [27]. There is still debate regarding the exact mechanism through which salt intake leads to hypertension $[28,29]$. One hypothesis is that increase in plasma volume and cardiac output results from dysfunctional handling of sodium by kidney [28]. Another is through systemic and renal vasodysfunction that salt-sensitive individuals are unable to 
TABLE 2: Prevalence, awareness, treatment, and control of hypertension among study participants by selected population characteristics.

\begin{tabular}{|c|c|c|c|c|c|c|c|c|}
\hline \multirow[t]{2}{*}{ Variable } & \multicolumn{2}{|c|}{$\begin{array}{l}\text { Hypertension among } \\
\text { study participants } \\
\quad(N=3000)\end{array}$} & \multicolumn{2}{|c|}{$\begin{array}{l}\text { Awareness among } \\
\text { hypertensive } \\
\text { participants } \\
(N=880)\end{array}$} & \multicolumn{2}{|c|}{$\begin{array}{l}\text { Treatment among } \\
\text { aware participants } \\
\qquad(N=302)\end{array}$} & \multicolumn{2}{|c|}{$\begin{array}{l}\text { Control among } \\
\text { participants on } \\
\text { treatment }(N=107)\end{array}$} \\
\hline & Hypertensive \% & $p$ value & Aware \% & $p$ value & Treated \% & $p$ value & Controlled \% & $p$ value \\
\hline Overall & 29.3 & - & 34.3 & - & 35.4 & - & 29.9 & - \\
\hline $\begin{array}{l}\text { Age (years) } \\
25-34 \\
34-44 \\
45-54 \\
55-64 \\
\end{array}$ & $\begin{array}{l}12.5 \\
29.2 \\
42.7 \\
53.2\end{array}$ & $<0.001$ & $\begin{array}{l}29.1 \\
28.6 \\
37.3 \\
40.6\end{array}$ & 0.016 & $\begin{array}{l}20.5 \\
24.3 \\
37.0 \\
49.4\end{array}$ & 0.001 & $\begin{array}{l}25.0 \\
38.9 \\
32.4 \\
25.0\end{array}$ & 0.705 \\
\hline $\begin{array}{l}\text { Gender } \\
\text { Male } \\
\text { Female } \\
\end{array}$ & $\begin{array}{l}31.4 \\
28.6 \\
\end{array}$ & 0.149 & $\begin{array}{l}21.3 \\
39.3 \\
\end{array}$ & $<0.001$ & $\begin{array}{r}38.5 \\
34.8 \\
\end{array}$ & 0.615 & $\begin{array}{l}15.0 \\
33.3 \\
\end{array}$ & 0.106 \\
\hline $\begin{array}{l}\text { Wealth status } \\
\text { Poorest } \\
\text { Poor } \\
\text { Middle } \\
\text { Rich } \\
\text { Richest }\end{array}$ & $\begin{array}{l}28.5 \\
28.4 \\
28.2 \\
30.2 \\
31.3\end{array}$ & 0.701 & $\begin{array}{l}33.8 \\
24.1 \\
28.8 \\
36.3 \\
45.2\end{array}$ & 0.001 & $\begin{array}{l}28.4 \\
35.3 \\
31.9 \\
36.5 \\
36.5\end{array}$ & 0.446 & $\begin{array}{l}52.6 \\
33.3 \\
20.0 \\
20.0 \\
29.0\end{array}$ & 0.143 \\
\hline $\begin{array}{l}\text { Marital status } \\
\text { Never married } \\
\text { Married } \\
\text { Separated/divorced/widowed }\end{array}$ & $\begin{array}{l}24.0 \\
28.9 \\
35.7 \\
\end{array}$ & 0.001 & $\begin{array}{l}29.3 \\
34.1 \\
37.9 \\
\end{array}$ & 0.374 & $\begin{array}{l}33.3 \\
32.2 \\
46.9 \\
\end{array}$ & 0.097 & $\begin{array}{l}11.1 \\
29.4 \\
36.7 \\
\end{array}$ & 0.336 \\
\hline $\begin{array}{l}\text { Education level } \\
\text { No formal education } \\
\text { Primary education } \\
\text { Secondary education } \\
\text { College/university } \\
\end{array}$ & $\begin{array}{l}34.0 \\
29.7 \\
20.0 \\
35.1\end{array}$ & 0.002 & $\begin{array}{c}31.7 \\
35.0 \\
37.3 \\
7.7\end{array}$ & 0.193 & $\begin{array}{c}40.6 \\
35.2 \\
26.3 \\
100.0 \\
\end{array}$ & 0.457 & $\begin{array}{c}38.5 \\
29.5 \\
20.0 \\
0.0\end{array}$ & 0.772 \\
\hline $\begin{array}{l}\text { Place of residence } \\
\text { Kilombero district } \\
\text { Ulanga district } \\
\end{array}$ & $\begin{array}{l}47.6 \\
52.4 \\
\end{array}$ & 0.092 & $\begin{array}{l}38.4 \\
30.6 \\
\end{array}$ & 0.014 & $\begin{array}{l}31.1 \\
40.4 \\
\end{array}$ & 0.089 & $\begin{array}{l}28.0 \\
31.6 \\
\end{array}$ & 0.687 \\
\hline $\begin{array}{l}\text { Occupation } \\
\text { Farmer } \\
\text { House wife } \\
\text { Employed } \\
\text { Business } \\
\text { Others }\end{array}$ & $\begin{array}{l}29.5 \\
21.5 \\
29.6 \\
27.5 \\
33.3\end{array}$ & 0.588 & $\begin{array}{l}34.5 \\
35.3 \\
37.5 \\
18.2 \\
46.2\end{array}$ & 0.492 & $\begin{array}{l}35.3 \\
16.7 \\
66.7 \\
25.0 \\
50.0\end{array}$ & 0.566 & $\begin{array}{c}30.0 \\
100.0 \\
0.0 \\
0.0 \\
33.3\end{array}$ & 0.457 \\
\hline $\begin{array}{l}\text { Current smoking status } \\
\text { No } \\
\text { Yes } \\
\end{array}$ & $\begin{array}{l}28.9 \\
35.8 \\
\end{array}$ & 0.052 & $\begin{array}{l}35.0 \\
25.4 \\
\end{array}$ & 0.122 & $\begin{array}{r}35.3 \\
37.5 \\
\end{array}$ & 0.859 & $\begin{array}{l}29.7 \\
33.3 \\
\end{array}$ & 0.850 \\
\hline $\begin{array}{l}\text { Current alcohol drinking status } \\
\text { No } \\
\text { Yes } \\
\end{array}$ & $\begin{array}{l}28.4 \\
33.2 \\
\end{array}$ & 0.022 & $\begin{array}{l}37.6 \\
23.0 \\
\end{array}$ & $<0.001$ & $\begin{array}{l}37.0 \\
26.6 \\
\end{array}$ & 0.183 & $\begin{array}{l}27.4 \\
50.0 \\
\end{array}$ & 0.107 \\
\hline $\begin{array}{l}\text { Use of raw table salt } \\
\text { No } \\
\text { Yes }\end{array}$ & $\begin{array}{l}17.7 \\
31.4 \\
\end{array}$ & $<0.001$ & $\begin{array}{l}17.7 \\
36.0\end{array}$ & 0.001 & $\begin{array}{l}21.4 \\
36.1 \\
\end{array}$ & 0.262 & $\begin{array}{l}66.7 \\
28.8 \\
\end{array}$ & 0.158 \\
\hline $\begin{array}{l}\text { Fruits consumption/week } \\
5-7 \text { days } \\
1-4 \text { days } \\
\text { Never }\end{array}$ & $\begin{array}{l}26.5 \\
29.8 \\
29.5 \\
\end{array}$ & 0.598 & $\begin{array}{l}31.7 \\
34.9 \\
33.1 \\
\end{array}$ & 0.825 & $\begin{array}{l}70.0 \\
32.6 \\
34.5 \\
\end{array}$ & 0.004 & $\begin{array}{l}28.6 \\
32.9 \\
20.0\end{array}$ & 0.534 \\
\hline $\begin{array}{l}\text { Consumption of vegetables/wee } \\
5-7 \text { days } \\
1-4 \text { days } \\
\text { Never } \\
\end{array}$ & $\begin{array}{l}30.5 \\
25.3 \\
36.6 \\
\end{array}$ & 0.077 & $\begin{array}{l}33.4 \\
37.4 \\
13.3 \\
\end{array}$ & 0.116 & $\begin{array}{l}35.9 \\
34.3 \\
50.0 \\
\end{array}$ & 0.876 & $\begin{array}{c}31.4 \\
25.0 \\
100.0 \\
\end{array}$ & 0.242 \\
\hline $\begin{array}{l}\text { History of diabetes mellitus } \\
\text { No } \\
\text { Yes }\end{array}$ & $\begin{array}{l}29.1 \\
51.7\end{array}$ & 0.008 & $\begin{array}{l}33.4 \\
86.7\end{array}$ & $<0.001$ & $\begin{array}{l}34.3 \\
61.5\end{array}$ & 0.044 & $\begin{array}{l}30.3 \\
25.0\end{array}$ & 0.753 \\
\hline
\end{tabular}


TABLE 2: Continued.

\begin{tabular}{|c|c|c|c|c|c|c|c|c|}
\hline \multirow[t]{2}{*}{ Variable } & \multicolumn{2}{|c|}{$\begin{array}{l}\text { Hypertension among } \\
\text { study participants } \\
\qquad(N=3000)\end{array}$} & \multicolumn{2}{|c|}{$\begin{array}{l}\text { Awareness among } \\
\text { hypertensive } \\
\text { participants } \\
(N=880)\end{array}$} & \multicolumn{2}{|c|}{$\begin{array}{l}\text { Treatment among } \\
\text { aware participants } \\
\qquad(N=302)\end{array}$} & \multicolumn{2}{|c|}{$\begin{array}{l}\text { Control among } \\
\text { participants on } \\
\text { treatment }(N=107)\end{array}$} \\
\hline & Hypertensive \% & $p$ value & Aware \% & $p$ value & Treated \% & $p$ value & Controlled \% & $p$ value \\
\hline \multicolumn{9}{|c|}{ Body mass index $\left(\right.$ BMI $\left.\left(\mathrm{kg} / \mathrm{m}^{2}\right)\right)$} \\
\hline Underweight & 12.9 & \multirow{4}{*}{$<0.001$} & 33.3 & \multirow{4}{*}{$<0.001$} & 50.0 & \multirow{4}{*}{0.770} & 50.0 & \multirow{4}{*}{0.937} \\
\hline Normal & 25.0 & & 27.2 & & 37.7 & & 30.0 & \\
\hline Overweight & 31.9 & & 35.9 & & 35.7 & & 28.6 & \\
\hline Obese & 41.9 & & 45.9 & & 31.9 & & 30.0 & \\
\hline
\end{tabular}

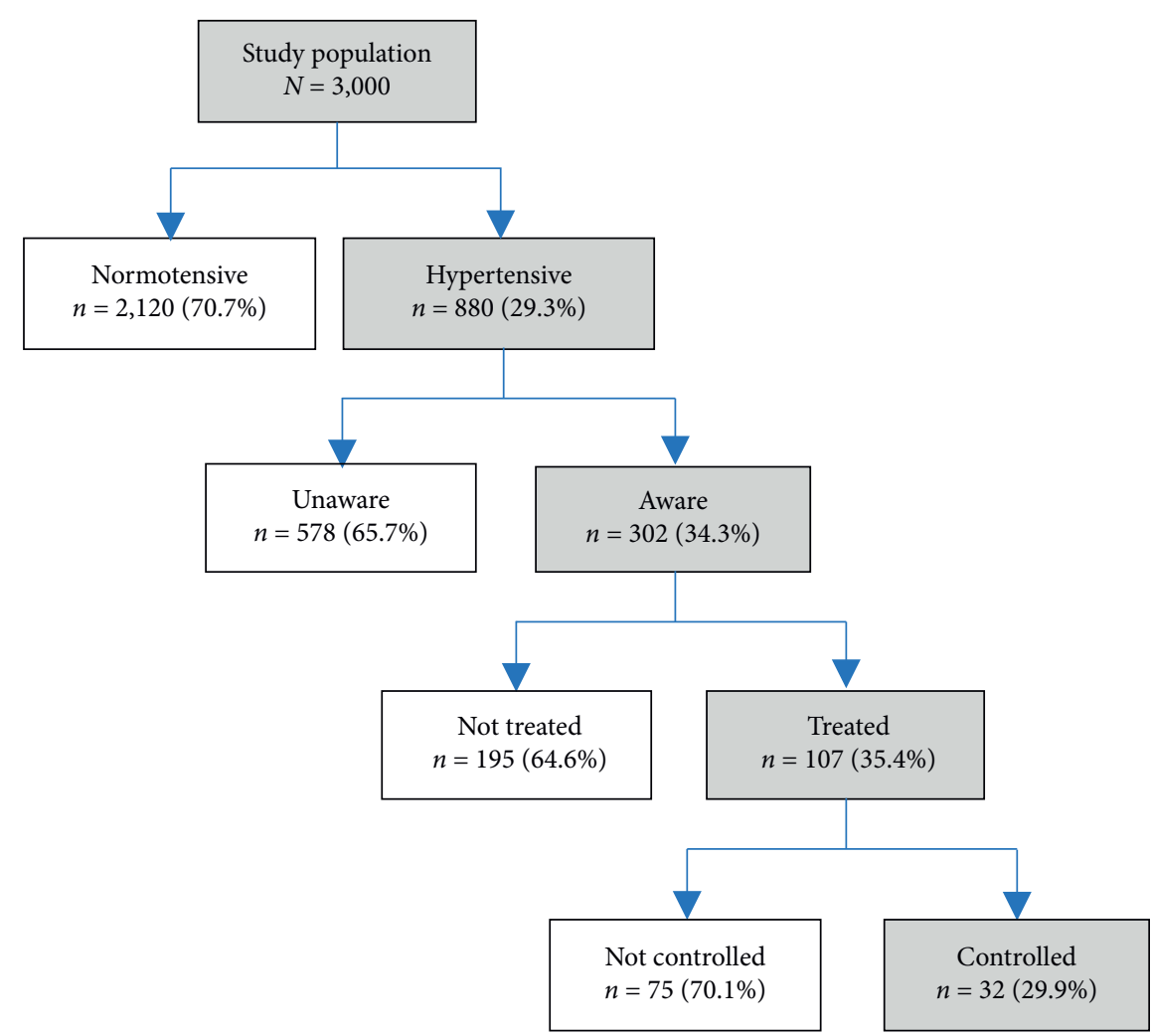

Figure 3: Prevalence, awareness, treatment, and control of hypertension among young and middle-aged population in Morogoro, Tanzania.

appropriately decrease systemic vascular resistance in response to increased sodium intake [29]. A higher proportion of Tanzanian has already been shown to be salt-sensitive (46.2\%) compared to Brazilians (36.4\%) and Japanese (16.7\%) and reported tight positive relation of salt with hypertension among Tanzanians [30].

4.2. Awareness, Treatment, and Control of Hypertension. Only one-third (34.3\%) of hypertensive participants were aware of their hypertension, while the remaining two-thirds (65.7\%) were undiagnosed. Despite being low, the rate of awareness in our study is higher than $9.4 \%$ reported in rural Mwanza [16] and pooled awareness level of $27 \%$ in SSA [9]. High proportion of undiagnosed hypertension can be attributable to unpreparedness of the healthcare system especially lower facilities in rural areas [31]. As a result, most individuals miss opportunity to be screened for hypertension despite their frequent contact with health facilities.

Awareness of hypertension was higher among older participants, women, individuals of higher socioeconomic status, overweight and obese participants, and individuals with a history of diabetes mellitus. Other studies in SSA have also reported higher rates of awareness of hypertension among older individuals and women [10, 32, 33]. Their higher awareness is proposed to be due to their higher contact with the healthcare system. Women privileged in that antenatal care services provide an opportunity for their health check including blood pressure [34]. Similarly, individuals of higher socioeconomic status have higher access to health care services compared to poor. Individuals who reported to drink alcohol had lower levels of awareness of their hypertension. These findings are consistent with reports from other studies $[10,35]$. 
TABLE 3: Crude and multivariate adjusted logistic regression models for determinants of hypertension in the study population $(N=3000)$.

\begin{tabular}{|c|c|c|c|c|}
\hline Variable & Crude odds ratio, COR (95\% CI) & $p$ & Adjusted odds ratio, AOR (95\% CI) & $p$ \\
\hline $\begin{array}{l}\text { Age (years) } \\
25-34 \\
35-44 \\
45-54 \\
55-64\end{array}$ & $\begin{array}{c}\text { Ref } \\
2.88(2.29-3.63) \\
5.21(4.10-6.63) \\
7.94(6.09-10.3)\end{array}$ & $<0.001$ & $\begin{array}{c}\text { Ref } \\
2.92(2.29-3.73) \\
5.45(4.20-7.07) \\
8.45(6.33-11.30)\end{array}$ & $<0.001$ \\
\hline $\begin{array}{l}\text { Gender } \\
\text { Male } \\
\text { Female } \\
\end{array}$ & $\begin{array}{c}\text { Ref } \\
0.88(0.74-1.05)\end{array}$ & 0.149 & $\begin{array}{c}\text { Ref } \\
0.89(0.72-1.10)\end{array}$ & 0.286 \\
\hline $\begin{array}{l}\text { Wealth status } \\
\text { Poorest } \\
\text { Poor } \\
\text { Middle } \\
\text { Rich } \\
\text { Richest }\end{array}$ & $\begin{array}{c}\text { Ref } \\
0.99(0.77-1.28) \\
0.98(0.77-1.25) \\
1.08(0.85-1.37) \\
1.14(0.90-1.45)\end{array}$ & 0.701 & - & - \\
\hline $\begin{array}{l}\text { Marital status } \\
\text { Never married } \\
\text { Married } \\
\text { Separated/divorced/widowed } \\
\end{array}$ & $\begin{array}{c}\text { Ref } \\
1.28(0.99-1.65) \\
1.76(1.30-2.37) \\
\end{array}$ & 0.001 & $\begin{array}{c}\text { Ref } \\
0.87(0.66-1.15) \\
0.88(0.63-1.22) \\
\end{array}$ & 0.620 \\
\hline $\begin{array}{l}\text { Education level } \\
\text { No formal education } \\
\text { Primary education } \\
\text { Secondary education } \\
\text { College/university } \\
\end{array}$ & $\begin{array}{c}\text { Ref } \\
0.82(0.63-1.06) \\
0.48(0.33-0.72) \\
1.05(0.51-2.15)\end{array}$ & 0.003 & $\begin{array}{c}\text { Ref } \\
0.97(0.73-1.28) \\
1.06(0.68-1.63) \\
1.59(0.71-3.53) \\
\end{array}$ & 0.615 \\
\hline $\begin{array}{l}\text { Place of residence } \\
\text { Kilombero district } \\
\text { Ulanga district }\end{array}$ & $\begin{array}{c}\text { Ref } \\
1.15(0.98(1.34)\end{array}$ & 0.092 & $\begin{array}{c}\text { Ref } \\
1.17(0.98-1.39)\end{array}$ & 0.079 \\
\hline $\begin{array}{l}\text { Occupation } \\
\text { Farmer } \\
\text { Housewife } \\
\text { Employed } \\
\text { Business } \\
\text { Others }\end{array}$ & $\begin{array}{c}\text { Ref } \\
0.65(0.38-1.13) \\
1.00(0.44-2.30) \\
0.90(0.55-1.49) \\
1.19(0.61-2.33)\end{array}$ & 0.594 & - & - \\
\hline $\begin{array}{l}\text { Current smoking status } \\
\text { No } \\
\text { Yes }\end{array}$ & $\begin{array}{c}\text { Ref } \\
1.37(0.99-1.88)\end{array}$ & 0.053 & $\begin{array}{c}\text { Ref } \\
1.12(0.77-1.63)\end{array}$ & 0.540 \\
\hline $\begin{array}{l}\text { Current alcohol drinking status } \\
\text { No } \\
\text { Yes }\end{array}$ & $\begin{array}{c}\text { Ref } \\
1.25(1.03-1.52) \\
\end{array}$ & 0.023 & $\begin{array}{c}\text { Ref } \\
0.93(0.74-1.15)\end{array}$ & 0.495 \\
\hline $\begin{array}{l}\text { Use of raw table salt } \\
\text { No } \\
\text { Yes }\end{array}$ & $\begin{array}{c}\text { Ref } \\
2.12(1.64-2.75) \\
\end{array}$ & $<0.001$ & $\begin{array}{c}\text { Ref } \\
2.27(1.73-2.99) \\
\end{array}$ & $<0.001$ \\
\hline $\begin{array}{l}\text { Fruits consumption/week } \\
5-7 \text { days } \\
1-4 \text { days } \\
\text { Never }\end{array}$ & $\begin{array}{c}\text { Ref } \\
1.16(0.83-1.63) \\
1.17(0.86-1.58) \\
\end{array}$ & 0.599 & - & - \\
\hline $\begin{array}{l}\text { Consumption of vegetable/week } \\
5-7 \text { days } \\
1-4 \text { days } \\
\text { Never }\end{array}$ & $\begin{array}{c}\text { Ref } \\
1.32(0.69-2.50) \\
0.84(0.71-0.99) \\
\end{array}$ & 0.077 & $\begin{array}{c}\text { Ref } \\
1.45(0.72-2.94) \\
0.84(0.70-1.00) \\
\end{array}$ & 0.084 \\
\hline $\begin{array}{l}\text { History of diabetes } \\
\text { No } \\
\text { Yes }\end{array}$ & $\begin{array}{c}\text { Ref } \\
2.61(1.25-5.43)\end{array}$ & 0.010 & $\begin{array}{c}\text { Ref } \\
1.53(0.69-3.35)\end{array}$ & 0.293 \\
\hline $\begin{array}{l}\text { Body mass index }\left(\mathrm{BMI}\left(\mathrm{kg} / \mathrm{m}^{2}\right)\right) \\
\text { Normal } \\
\text { Overweight } \\
\text { Obese } \\
\text { Underweight }\end{array}$ & $\begin{array}{c}\text { Ref } \\
1.41(1.17-1.70) \\
2.17(1.75-2.67) \\
0.45(0.24-0.82)\end{array}$ & $<0.001$ & $\begin{array}{c}\text { Ref } \\
1.53(1.26-1.88) \\
2.58(2.04-3.28) \\
0.41(0.21-0.78)\end{array}$ & $<0.001$ \\
\hline
\end{tabular}


TABLE 4: Crude and multivariate adjusted logistic regression models for determinants of awareness of hypertension status among hypertensive individuals $(N=880)$.

\begin{tabular}{|c|c|c|c|c|}
\hline Variable & Crude odds ratio, COR (95\% CI) & $p$ value & Adjusted odds ratio, AOR (95\% CI) & $p$ value \\
\hline \multicolumn{5}{|l|}{ Age (years) } \\
\hline $25-34$ & Ref & \multirow{4}{*}{0.016} & Ref & \multirow{4}{*}{$<0.001$} \\
\hline $35-44$ & $0.97(0.62-1.54)$ & & $0.92(0.57-1.51)$ & \\
\hline $45-54$ & $1.45(0.93-2.67)$ & & $1.68(1.04-2.74)$ & \\
\hline $55-64$ & $1.67(1.05-2.64)$ & & $2.05(1.24-3.39)$ & \\
\hline \multicolumn{5}{|l|}{ Gender } \\
\hline Male & Ref & & Ref & \multirow[b]{2}{*}{$<0.001$} \\
\hline Female & $2.39(1.69-3.38)$ & $<0.001$ & $2.47(1.67-3.66)$ & \\
\hline \multicolumn{5}{|l|}{ Wealth status } \\
\hline Poorest & Ref & \multirow{5}{*}{0.001} & Ref & \multirow{5}{*}{0.003} \\
\hline Poor & $0.62(0.38-1.01)$ & & $0.59(0.35-1.00)$ & \\
\hline Middle & $0.79(0.51-1.24)$ & & $0.68(0.42-1.10)$ & \\
\hline Rich & $112(0.74-1.69)$ & & $0.94(0.59-1.48)$ & \\
\hline Richest & $1.61(1.07-2.43)$ & & $1.48(0.94-2.32)$ & \\
\hline \multicolumn{5}{|l|}{ Marital status } \\
\hline Never married & Ref & \multirow{3}{*}{0.375} & \multirow{3}{*}{-} & \multirow{3}{*}{-} \\
\hline Married & $1.25(0.77-2.01)$ & & & \\
\hline Separated/divorced/widowed & $148(0.85-2.53)$ & & & \\
\hline \multicolumn{5}{|l|}{ Education level } \\
\hline No formal education & Ref & \multirow{4}{*}{0.292} & \multirow{4}{*}{-} & \multirow{4}{*}{-} \\
\hline Primary education & $1.16(0.74-1.81)$ & & & \\
\hline Secondary education & $1.28(0.63-2.59)$ & & & \\
\hline College/university & $0.18(0.02-1.44)$ & & & \\
\hline \multicolumn{5}{|l|}{ Place of residence } \\
\hline Kilombero district & Ref & & Ref & \\
\hline Ulanga district & $0.71(0.53-0.93)$ & 0.015 & $0.80(0.59-1.09)$ & 0.156 \\
\hline \multicolumn{5}{|l|}{ Occupation } \\
\hline Farmer & Ref & & & \\
\hline Housewife & $1.03(0.38-2.83)$ & & & \\
\hline Employed & $1.14(0.27-4.80)$ & 0.519 & - & - \\
\hline Business & $0.42(0.14-1.26)$ & & & \\
\hline Others & $1.63(0.54-4.89)$ & & & \\
\hline Current smoking status & & & & \\
\hline No & Ref & & Ref & \\
\hline Yes & $0.63(0.35-1.13)$ & 0.124 & $1.51(0.76-2.97)$ & 0.238 \\
\hline Current alcohol drinking status & & & & \\
\hline No & Ref & & Ref & \\
\hline Yes & $0.49(0.34-0.71)$ & $<0.001$ & $0.49(0.32-0.74)$ & 0.001 \\
\hline Use of raw table salt & & & & \\
\hline No & Ref & & Ref & \\
\hline Yes & $2.61(1.44-4.73)$ & 0.002 & $3.20(1.69-6.06)$ & $<0.001$ \\
\hline Fruits consumption/week & & & & \\
\hline 5-7 days & Ref & & & \\
\hline $1-4$ days & $1.07(0.57-1.98)$ & 0.825 & - & - \\
\hline Never & $1.15(0.66-2.01)$ & & & \\
\hline Consumption of vegetables/weel & & & & \\
\hline $5-7$ days & Ref & & Ref & \\
\hline $1-4$ days & $0.31(0.07-1.37)$ & 0.138 & $0.35(0.07-1.64)$ & 0.140 \\
\hline Never & $1.19(0.89-1.60)$ & & $1.26(0.91-1.75)$ & \\
\hline History of diabetes & & & & \\
\hline No & Ref & & Ref & \\
\hline Yes & $0.08(0.02-0.34)$ & 0.001 & $12.58(2.61-60.55)$ & 0.002 \\
\hline Body mass index (BMI $\left.\left(\mathrm{kg} / \mathrm{m}^{2}\right)\right)$ & & & & \\
\hline Normal & Ref & & Ref & \\
\hline Overweight & $1.50(1.07-2.09)$ & $<0.001$ & $1.51(1.05-2.16)$ & 0.025 \\
\hline Obese & $2.27(1.59-3.23)$ & & $2.24(1.44-3.17)$ & \\
\hline Underweight & $1.34(0.39-4.54)$ & & $2.14(0.60-7.60)$ & \\
\hline
\end{tabular}


Surprisingly, individuals who reported using raw table salt had higher levels of awareness of their hypertension status, indicating lack of knowledge regarding healthy lifestyles for prevention and control of hypertension in this rural Tanzanian population. Overall shortage of healthcare personnel [36], and more importantly, lack of trained staff for provision of hypertension services at lower health facilities [31], is the underlying reason for continued unhealthy behaviors among hypertensive individuals. Thus, efforts to prevent and control hypertension should ensure enabling lower health facilities to impart knowledge about risk factors, conduct routine screening, and proper management of hypertension.

Treatment among individual who were aware of their hypertension was $35.4 \%$, which is lower compared to other reports in Tanzania [15-17]. Treatment rate among hypertensive individuals regardless of their awareness status was only $12.2 \%$, which is also lower than the pooled treatment rate of $18.0 \%$ from systematic review of studies conducted in SSA [9]. Treatment rates were higher among older and diabetic individuals and those who used raw table salt. Rachel et al. found main reasons for not being on treatment to be lack of symptoms, not being prescribed, and finishing a single course of treatment [37].

Less than one-third of study participants on treatment had controlled blood pressure. In contrast, other studies in Tanzania have reported much lower hypertension control rates than found in this study $[15,37,39]$. Blood pressure control has been reported to be higher among individuals with health insurance $[38,48]$. Although, the two study districts have good coverage of community health fund (CHF), which offers limited health benefit package to primary healthcare level, we did not assess ownership of CHF cards to draw its associations with hypertension treatment and control. Nonetheless, regular clinic attendance alone cannot guarantee blood pressure control [49]. Lack of trained health personnel and unavailability or frequent stock out of antihypertensive medications are health system challenges facing treatment and control of hypertension in rural Tanzanian settings $[31,50]$. As such, community-based primary prevention strategies are the best buys in such settings where access and quality of healthcare services is still low.

This study has both strengths and limitations. Key strengths of this study are large sample size and repeat blood pressure measurements to confirm high blood pressure. Use of three measurements taken on a single session to define hypertension is likely to overestimate the prevalence of hypertension by $5.4 \%-23.4 \%[51,52]$. Thus, our study provides a better estimate on the burden of hypertension in this population. Limitations to our analysis include its crosssectional design, which does not allow drawing conclusions on causal associations between hypertension and independent variables. The sampled population may not be truly representative of the Tanzanian rural population, and these finding should be interpreted with caution. Moreover, we did not collect detailed information of dietary intake using food frequency questionnaire and physical activity, both of which are known to be associated with hypertension.

\section{Conclusion}

The prevalence of hypertension in this rural Tanzanian population was high. Levels of awareness, treatment, and control were unacceptably low. Older age, marital status, education level, smoking and alcohol use, use of raw table salt, a history of diabetes mellitus, and overweight/obesity were identified to be associated with hypertension. These findings call for screening and prevention strategies to curb this increasing burden of hypertension. Communitylevel health promotion campaigns should be implemented to increase awareness, treatment, and control rates for hypertension, while ensuring routine screening for hypertension is conducted to all individuals regardless of their presenting complaints. Priority should be given to older and overweight and or obese individuals due to their increased risk for hypertension. Healthy lifestyle changes should be encouraged for prehypertensive individuals to halt their progression to full blown hypertension. If implemented fully, such strategies would ensure prevention and control not only of hypertension but also other CVD risk factors.

\section{Abbreviations \\ BMI: Body mass index \\ CHF: Community health fund \\ CHW: Community health worker \\ CVDs: Cardiovascular diseases \\ DBP: Diastolic blood pressure \\ DHS: Demographic health surveys \\ HICs: High-income countries \\ LMICs: Low- and middle-income countries \\ NCDs: Noncommunicable diseases \\ SBP: $\quad$ Systolic blood pressure \\ SSA: Sub-Saharan Africa \\ WHO: World Health Organization.}

\section{Data Availability}

The data used to support the findings of this study are available from the corresponding author upon request.

\section{Ethical Approval}

This study was approved by the Muhimbili University of Health and Allied Sciences (MUHAS-REC-1-2017-070).

\section{Consent}

Objectives, procedures, importance, risks, and benefits of the study were explained to potential participants in advance. Voluntary participation and freedom to withdraw were emphasized, and all participants signed an informed consent form prior to joining the study. Participants with identified risk factors received health education and those with raised blood pressure were referred to nearby health care facility for further investigation, diagnosis, and management as per national guidelines. 


\section{Disclosure}

The funders had no role in study design, data collection and analysis, preparation of the manuscript, or decision to publish.

\section{Conflicts of Interest}

The authors declare that they have no conflicts of interest.

\section{Authors' Contributions}

AJM, MN, and DPU conceived the study. AJM and AA led the data collection process. AJM wrote the analysis plan and conducted data analysis with support from RNM and MN. AJM conducted literature review and wrote the first draft of the manuscript with support from AA under the supervision of MN and DPU. RNM, BFS, GL, DK, ATK, MMS, MN, and DPU critically reviewed and provided intellectual input to the manuscript. RNM and MN suggested additional analyses. AJM made the proposed revisions and finalized the manuscript. All authors read and approved the final version of the manuscript.

\section{Acknowledgments}

The authors are grateful to research assistants who participated in data collection for this study. The authors are also grateful to Ulanga and Kilombero districts authorities for their support and introductions to respective village authorities that ensured smooth data collection. The authors would like to thank participants for their time and great contribution to these findings. This study was supported by the Bernard Lown Scholars in Cardiovascular Health Program at Harvard T.H Chan School of Public Health (Agreement \#BLSCHP-1901) to Dr. Alfa Muhihi and the SIDA small grant award from Muhimbili University of Health and Allied Sciences to Dr. Amani Anaeli.

\section{References}

[1] G. A. Mensah, G. A. Roth, and V. Fuster, "The global burden of cardiovascular diseases and risk factors," Journal of the American College of Cardiology, vol. 74, no. 20, pp. 2529-32, 2019.

[2] A. V. Chobanian, G. L. Bakris, H. R. Black et al., "The Seventh Report of the Joint National Committee on Prevention, Detection, Evaluation, and Treatment of High Blood Pressure," JAMA, vol. 289, no. 19, pp. 2560-2572, 2003.

[3] P. M. Kearney, M. Whelton, K. Reynolds et al., "Global burden of hypertension: analysis of worldwide data," Lancet, vol. 365, no. 9455, pp. 217-223, 2005.

[4] G. Danaei, Y. Lu, G. M. Singh et al., "Cardiovascular disease, chronic kidney disease, and diabetes mortality burden of cardio metabolic risk factors from 1980 to 2010: a comparative risk assessment," Lancet Diabetes Endocrinology, vol. 2, no. 8, pp. 634-647, 2014.

[5] R. N. Haldar, "Global brief on hypertension: silent killer, global public health crisis," Indian Journal of Physical Medicine and Rehabilitation, vol. 24, no. 1, 2013.
[6] K. T. Mills, J. D. Bundy, T. N. Kelly et al., "Global disparities of hypertension prevalence and control," Circulation, vol. 134, no. 6, pp. 441-450, 2016.

[7] WHO, NCDs | Know the NCD Targets, World Health Organization, Geneva, Switzerland, 2017, https://www.who.int/ beat-ncds/take-action/targets/en/.

[8] F. X. Gómez-Olivé, S. A. Ali, F. Made et al., "Regional and sex differences in the prevalence and awareness of hypertension: an H3Africa AWI-Gen study across 6 sites in sub-saharan africa," Global Heart, vol. 12, no. 2, pp. 81-90, 2017.

[9] F. Ataklte, S. Erqou, S. Kaptoge et al., "Burden of undiagnosed hypertension in sub-saharan africa: a systematic review and meta-analysis," Hypertension, vol. 65, no. 2, pp. 291-298, 2015.

[10] S. F. Mohamed, M. K. Mutua, R. Wamai et al., "Prevalence, awareness, treatment and control of hypertension and their determinants: results from a national survey in Kenya," BMC Public Health, vol. 18, 2018.

[11] A. B. Swai, D. G. McLarty, H. M. Kitange et al., "Low prevalence of risk factors for coronary heart disease in rural Tanzania," International Journal of Epidemiology, vol. 22, no. 4, pp. 651-659, 1993.

[12] M. Mayige, G. Kagaruki, K. Ramaiya, and A. Swai, "Non communicable diseases in Tanzania: a call for urgent action," Tanzania Journal of Health Research, vol. 13, no. 5, pp. 1-11, 2011.

[13] M. A. Njelekela, R. Mpembeni, A. Muhihi et al., "Genderrelated differences in the prevalence of cardiovascular disease risk factors and their correlates in urban Tanzania," BMC Cardiovascular Disorders, vol. 9, 2009.

[14] G. Kagaruki and M. Mary, Tanzania Steps Survey Report: Ministry of Health and Social Welfare and National Institute for Medical Research, ResearchGate, Berlin, Germany, 2016.

[15] M. S. Muhamedhussein, Z. I. Nagri, and K. P. Manji, "Prevalence, risk factors, awareness, and treatment and control of hypertension in Mafia Island, Tanzania," International Journal of Hypertension, vol. 2016, Article ID 1281384, 5 pages, 2016.

[16] N. R. Mosha, M. Mahande, A. Juma et al., "Prevalence, awareness and factors associated with hypertension in North West Tanzania," Global Health Action, vol. 10, no. 1, 2017.

[17] S. Narh-Bana, T. Chirwa, M. Mwanyangala, and R. Nathan, "Adult deaths and the future: a cause-specific analysis of adult deaths from a longitudinal study in rural Tanzania 2003-2007," Tropical Medicine and International Health, vol. 17, pp. 1396-1404, 2012.

[18] D. Beguy, P. Elung'ata, B. Mberu et al., "Health \& demographic surveillance system profile: the nairobi urban health and demographic surveillance system (NUHDSS)," International Journal of Epidemiology, vol. 44, no. 2, pp. 462-471, 2015.

[19] WHO, NCDs WHO STEPS Sample Size Calculator and Sampling Spreadsheet, WHO, Geneva, Switzerland, 2015.

[20] S. Vyas and L. Kumaranayake, "Constructing socio-economic status indices: how to use principal components analysis," Health Policy and Planning, vol. 21, no. 6, pp. 459-468, 2006.

[21] J. Gardner and A. Oswald, "How is mortality affected by money, marriage, and stress?" Journal of Health Economics, vol. 23, no. 6, pp. 1181-1207, 2004.

[22] Z. Zhang and M. D. Hayward, "Gender, the marital life course, and cardiovascular disease in late midlife," Journal of Marriage and Family, vol. 68, no. 3, pp. 639-657, 2006.

[23] M. Y. Liu, N. Li, W. A. Li, and H. Khan, "Association between psychosocial stress and hypertension: a systematic review and 
meta-analysis," Neurological Research, vol. 39, no. 6, pp. 573-580, 2017.

[24] J. S. D. da Costa, F. C. Barcellos, M. L. Sclowitz et al., "Hypertension prevalence and its associated risk factors in adults: a population-based study in Pelotas," Arquivos Brasileiros de Cardiologia, vol. 88, no. 1, pp. 59-65, 2007.

[25] S. Basu and C. Millett, "Social epidemiology of hypertension in middle-income countries: determinants of prevalence, diagnosis, treatment, and control in the WHO SAGE study," Hypertension, vol. 62, no. 1, pp. 18-26, 2013.

[26] M. C. Zatu, J. P. Van Rooyen, A. Kruger, and A. E. Schutte, "Alcohol intake, hypertension development and mortality in black South Africans," European Journal of Preventive Cardiology, vol. 23, no. 3, pp. 308-315, 2016.

[27] T. M. Frisoli, R. E. Schmieder, T. Grodzicki, and F. H. Messerli, "Salt and hypertension: is salt dietary reduction worth the effort?" American Journal of Medicine, vol. 125, no. 5, pp. 433-439, 2012.

[28] M. J. Bloch, "Salt-induced hypertension-what do we really know about the mechanism?" Journal of American Society of Hyperten, vol. 10, no. 7, pp. 545-546, 2016.

[29] R. C. Morris, O. Schmidlin, A. Sebastian, M. Tanaka, and T. W. Kurtz, "Vasodys function that involves renal vasodysfunction, not abnormally increased renal retention of sodium, accounts for the initiation of salt-induced hypertension," Circulation, vol. 133, no. 9, pp. 881-893, 2016.

[30] J. P. Mtabaji, Y. Moriguchi, Y. Nara et al., "Ethnic differences in salt sensitivity: genetic or environmental factors?" Clinical and Experimental Pharmacology and Physiology, vol. 20, pp. 65-67, 1992.

[31] D. Bintabara and B. C. T. Mpondo, "Preparedness of lowerlevel health facilities and the associated factors for the outpatient primary care of hypertension: evidence from Tanzanian national survey," PLoS One, vol. 13, no. 2, Article ID e0192942, 2018.

[32] F. M. Goma, S. H. Nzala, O. Babaniyi et al., "Prevalence of hypertension and its correlates in Lusaka urban district of Zambia: a population based survey," International Archives of Medicine, vol. 4, no. 1, 2011.

[33] J. E. Pires, Y. V. Sebastião, A. J. Langa, and S. V. Nery, "Hypertension in Northern Angola: prevalence, associated factors, awareness, treatment and control," BMC Public Health, vol. 13, no. 1, p. 90, 2013.

[34] M. Pereira, N. Lunet, A. Azevedo, and H. Barros, "Differences in prevalence, awareness, treatment and control of hypertension between developing and developed countries," Journal of Hyperten, vol. 27, no. 5, pp. 963-975, 2009.

[35] S. Sengul, T. Akpolat, Y. Erdem et al., "Changes in hypertension prevalence, awareness, treatment, and control rates in Turkey from 2003 to 2012," Journal of Hypertension, vol. 34, no. 6, pp. 1208-1217, 2016.

[36] N. Sirili, A. Kiwara, O. Nyongole et al., "Addressing the human resource for health crisis in Tanzania: the lost in transition syndrome," Tanzania Journal of Health Research, vol. 16, no. 2, 2014.

[37] R. M Zack, K. Irema, P. Kazonda et al., "Determinants of high blood pressure and barriers to diagnosis and treatment in Dar es Salaam, Tanzania," Journal of Hypertension, vol. 34, no. 12, pp. 2353-2364, 2016.

[38] A. A. Oso, A. A. defurin, M. M. Benneman et al., "Health insurance status affects hypertension control in a hospital based internal medicine clinic," International Journal of Cardiology: Hypertension, vol. 1, 2019.
[39] S. W. Galson, C. A. Staton, F. Karia et al., "Epidemiology of hypertension in Northern Tanzania: a community-based mixed-methods study," BMJ Open, vol. 7, no. 11, 2017.

[40] M. J. Dewhurst, F. Dewhurst, W. K. Gray et al., "The high prevalence of hypertension in rural-dwelling Tanzanian older adults and the disparity between detection, treatment and control: a rule of sixths?" Journal of Human Hypertension, vol. 27, no. 6, pp. 374-380, 2013.

[41] M. Joffres, E. Falaschetti, C. Gillespie et al., "Hypertension prevalence, awareness, treatment and control in national surveys from England, the USA and Canada, and correlation with stroke and ischaemic heart disease mortality: a crosssectional study," BMJ Open, vol. 3, no. 8, 2013.

[42] R. B. Awuah, J. K. Anarfi, C. Agyemang, G. Ogedegbe, and A. De-Graft Aikins, "Prevalence, awareness, treatment and control of hypertension in urban poor communities in Accra, Ghana," Journal of Hypertension, vol. 32, pp. 1203-1210, 2014.

[43] E. Pinto, "Blood pressure and ageing," Postgraduate Medical Journal, vol. 83, no. 976, pp. 109-114, 2007.

[44] J. N. Singh and A. S. Dhamoon, Physiology, Blood Pressure Age Related Changes, StatPearls, Treasure Island, FL, USA, 2018.

[45] H. M. Schwandt, J. Coresh, and M. J. Hindin, "Marital status, hypertension, coronary heart disease, diabetes, and death among African American women and men: incidence and prevalence in the atherosclerosis risk in communities (ARIC) study participants," Journal of Family Issues, vol. 31, no. 9, pp. 1211-1229, 2010.

[46] O. A. Sanuade, S. Boatemaa, and M. K. Kushitor, "Hypertension prevalence, awareness, treatment and control in Ghanaian population: evidence from the Ghana demographic and health survey," PLoS One, vol. 13, no. 11, 2018.

[47] R. Hilz and M. Wagner, "Marital status, partnership and health behaviour: findings from the German ageing survey (DEAS)," Comparative Population Studies, vol. 43, pp. 65-98, 2018.

[48] M. E. Hendriks, F. W. Wit, M. T. Roos et al., "Hypertension in sub-saharan africa: cross-sectional surveys in four rural and urban communities," PLoS One, vol. 7, no. 3, Article ID e32638, 2012.

[49] J. Maginga, M. Guerrero, E. Koh et al., "Hypertension control and its correlates among adults attending a hypertension clinic in Tanzania," Journal of Clinical Hypertension, vol. 18, no. 3, pp. 207-216, 2016.

[50] J. Adinan, R. Manongi, G. A. Temu et al., "Preparedness of health facilities in managing hypertension \& diabetes mellitus in Kilimanjaro, Tanzania: a cross sectional study," BMC Health Service Research, vol. 19, no. 1, p. 537, 2019.

[51] A. J. Price, A. C. Crampin, A. Amberbir et al., "Prevalence of obesity, hypertension, and diabetes, and cascade of care in sub-Saharan Africa: a cross-sectional, population-based study in rural and urban Malawi," Lancet Diabetes and Endocrinology, vol. 6, no. 3, pp. 208-222, 2018.

[52] A. Dzudie, A. P. Kengne, W. F. Muna et al., "Prevalence, awareness, treatment and control of hypertension in a selfselected sub-Saharan African urban population: a cross-sectional study," BMJ Open, vol. 2, no. 4, 2012. 